\title{
Evil Human Nature: From the Perspectives of St. Augustine and Hsun Tzu
}

\author{
Xiajun Hu, Jing Guo \\ School of Foreign Language, Wuhan University of Technology, Wuhan, China. \\ Email: betty729@sina.com,jingguo89@gmail.com \\ Received September 26 $6^{\text {th }}$, 2011; revised October 28 ${ }^{\text {th }}, 2011$; accepted November $10^{\text {th }}, 2011$.
}

\begin{abstract}
The view of evil human nature is important in Chinese and western cultures. The thesis chooses evil human in St. Augustine's thoughts and Hsun Tzu's thoughts to compare and analyze evil in these two. St. Augustine, who is called "the Saint of God", views the definition of evil, the resource of it, and salvations of it from the aspect of religious beliefs. He considers that evil is the privation of goodness and is not created by God. Because God is omnipotent and all-good, it is impossible for God to create evil. Evil results from the free will of human beings themselves. If people want to attain their salvations, they should use their free will to choose good will and follow the goodness given by God. Hsun Tzu, one of Confucian scholars, puts forward evil human nature which is totally different from good human nature in Confucianism. He views the definition of evil, the source of it, and ways to change evil into good from the angle of social reality in Warring States Period. In Hsun Tzu's views, evil results from the uninhibited extension of sound physical needs and desires for living. Hsun Tzu believes that human nature is evil and goodness comes from nurture, therefore, converting evil into good is to change human nature through nurturing. By further comparison and analysis, the thesis further looks into these two perspectives from their differences and similarities. It states their differences from five aspects: backgrounds, ways to change evil to good, categories, historical status, and positions of human beings. Apart from those, the thesis also refers to their similarities to complement the comparative analysis. From comparison and analysis, we can draw two conclusions: first, evil human nature from Hsun Tzu is simple in connotation and relatively objective compared with the view of St. Augustine; second, St. Augustine thinks that human beings are equal in front of evil, which has positive significance compared with the ideas posed by Hsun Tzu who insists on the distinction between saint and ordinary people, between monarchs and their subjects.
\end{abstract}

Keywords: Augustine, Hsun Tzu, Evil, Free Will, Nurture

\section{Introduction}

In this paper, evil human nature in St. Augustine's thoughts and Hsun Tzu's thoughts is compared under scrutiny. In the light of St. Augustine, evil is the privation of goodness. God is omniscient and omnipotent, and creates every thing. But evil is not created by God, because God is all-good. Besides, according to his views, the source of evil is the free will of people. God creates every thing, definitely including human beings. When human beings are created, they are also endowed with free will to accept or reject goodness. Compared with the view of St. Augustine, evil human nature proposed by Hsun Tzu may be understood from two aspects what evil is and what human nature is. Evil has two levels of meaning physical evil and moral evil. In the light of Hsun Tzu, he emphasizes on moral evil. His human nature has three levels of meaning: first, it is not nurtured but inborn; second, it is simple and plain without any polish; third, it contains all kinds of sound physical needs and desires for living. The source of evil in the views of Hsun Tzu is from the uninhibited extension of sound physical needs for living. Through observing their explanations about evil human nature, we can see their differences. By further analysis, the thesis presents their differences from five aspects: their different backgrounds, ways to convert evil into good, categories, positions of human beings, and their historical status. St. Augustine puts forward his views from the aspect of religious beliefs. He admits the existence of God and God creating human beings. He also considers that the relationship between God and human beings is in the central part of his theories. On the contrary, Hsun Tzu may be an atheist on the issue of evil human nature. He poses his views from the aspect of social reality. He focuses on the relationship between saints and ordinary people, monarchs and their subjects. Through the comparison of evil in these two, it draws two conclusions. In the later stage of St. Augustine, he raises the idea of predestination which expresses that God has a plan and foresees everything in the future, including the choice of evil. So, why does not God prevent the occurrence of evil? God has foreseen that people choose evil. However, they are also entitled to the choice between evil and good. It is found that there is an apparent contradiction in the theories of St. Augustine. In comparison with St. Augustine's radically contradictory views, Hsun Tzu's views are relatively simple and easy to understand. However, when referring to positions of human beings in front of evil, St. Augustine deems that human beings, no matter evil or not, are equal in the eyes of God; on the contrary, based on the social reality Hsun Tzu believes that saints and monarchs are different from ordinary people and their subjects who are subordinate to them.

\section{Evil, Free Will, Theodicy and Predestination Posed by St. Augustine}

\section{Evil and Theodicy}

On evil human nature, St. Augustine gives his own explanations. He refines his views from the Christianity doctrines sin. Then, what is sin?

Whatever it is, it is both astonishingly deep and deeply elu- 
sive (Plantinga, 2000). According to Saint Augustine's Doctrine of Original Sin, sin and evil exists because of Adam and Eve's defiance of God and since we are all descendants of Adam and eve, we are automatically born into sin and are thus, evil choice. Since we are naturally evil, we as human beings can commit evil just for the sake of committing evil, or even to attempt a taste of God's powers (Duong, 2009).

From the quotation above, it can be found that the view of St. Augustine has something to do with the relationship between God and evil. So, it is necessary to introduce what the theodicy is. From the new world encyclopedia, theodicy is a specific branch of theology and philosophy, which attempts to solve the problem of evil the problem that arises when trying to reconcile the observed existence of evil in the world with the assumption of the existence of God who is fully good and almighty. That is to say, theodicy is an attempt to explain the coexistence of God and evil. It studies the relationship between God and evil. In accordance with Hexter's Augustinian Theodicy.

St. Augustine created a theodicy that tried to explain the evil in the world by searching for an alternate source for this evil than God. The first premises of this argument is that evil is not itself an entity. Instead it is the state in which there is a lack, or perversion (a "privation") of good. This is necessary, because as all things come from God if evil were an entity then God must have originally created it, and this would be inconsistent with his benevolence. Secondly, human beings were created by God with free will. This gives them the potential to do well, but does not enforce it. This is backed up by two points (Hexter, 2009).

God is omnipotent, omniscient and all-good. Evil is not an entity or separate being by itself. According to St. Augustine, evil is a privation of good. God creates human beings, and He is good. So, a conclusion can be drawn that God does not have a bearing on evil and is not responsible for the cause of evil. In other words, God does not cause or create evil. Actually, about the problem of evil, it has other views. For example, one way to understand the origin of evil is a syllogism: 1) God creates every thing; 2) evil is a thing; 3) so, God creates evil too. This formulation is devastating for Christianity. From these, we can draw a conclusion that God is not all-good, for he creates evil. To this opposite view, St. Augustine solves the problem from a different angle. In Koukl and Gregory's Augustine on Evil, he asked.

Do we have any convincing evidence that a good God exists? If independent evidence leads us to conclude that God exists and is good, then He would be incapable of creating evil. Something else, then, must be its source. If Augustine's approach is fair, it prompts a pair of syllogisms that lead to a different conclusion. First: 1) All things that God created are good; 2) evil is not good; 3) therefore, evil was not created by God. Second: 1) God created every thing; 2) God did not create evil; 3) therefore, evil is not a thing (Koukl, 2005).

Through this syllogism from the assumption of St. Augustine, it returns to his view of evil that evil is the privation of goodness.

\section{Free Will and Predestination}

God is not responsible for evil which originates from the free will of human beings. Simply speaking, free will which is ordained by God means that people have choices in front of evil and goodness. Evil results from the choice of human beings' free will. St. Augustine defines "good will as a will by which we seek to live a good and upright life and to attain perfect wisdom which, of course, assumes that it is free." ${ }^{\text {"1 }}$ In the oppo-

${ }^{1}$ http://www.catholic.org (last checked 2009) sition to good will, bad will which attributes to evil is a will to choose desires or values irrationally. "He freely bestows upon us voluntary assent, earnest effort, and the power to perform works of fervent charity" (Augustine, 1953). Free will is St. Augustine's theory in his early years, which is obviously contradictory to his theory-Predestination-in his later years. Then, what is the predestination? God is almighty and omnipotent. He foresees the future of every thing. We can understand that God foresees human beings to choose evil. Because evil is foreseen by God, evil should be laid at God's feet. Why does God permit the existence of evil? Why does not God help human beings to avoid evil? In the later years of St. Augustine, in order to combat with Pelages' view that God does not have a plan; St. Augustine advances his idea of predestination. In John A. Battle's How Can God Be Just or Ordain, "For Augustine the other side of the equation was God's total sovereignty. Thus even the devil and his demons are completely under God's control. Demons can do nothing 'unless where they are permitted by the deep and secret providence of God, and then only as far as they are permitted"' (Battle, 1996); this quotation may be a bit of exaggeration, but it completely expresses the meaning of predestination. God permits the existence of evil in order to show his attributes and glorify himself. When understanding free will and predestination, it can be found that there is the self-contradiction in St. Augustine's views.

\section{The Idea of Evil in Hsun Tzu's Thoughts}

\section{Evil in Hsun Tzu's Thoughts}

Hsun Tzu may be an atheist when evil human nature is concerned. Philosophy is an essentially-contested notion (Campbell, 2001). From the angle of social reality to see evil, he regards that Heaven is not responsible for human actions, which means that evil has nothing to do with Heaven but human beings themselves. Compared with the thoughts of evil by St. Augustine, the thoughts of it by Hsun Tzu is relatively simple. His concept is sole and not relevant with Heaven or God. Desires for living are the main cause of human evil. If human beings do not control their desires, evil will follow. In view of Herbert Plutschow's Hsun Tzu and the Ancient Chinese Philosophical Debate on Human Nature,

The nature of man is such that he is born with a fondness for profit. If he indulges in this fondness, it will lead him into wrangling and strife and all sense of courtesy and humility will disappear. He is born with a feeling of envy and hate, and if he indulges in these, they will lead him into violence and crime, and all sense of loyalty and good faith will disappear (Plutschow, 2002).

From this quotation, it can be found that the ideas of evil by Hsun Tzu are greatly different from that by St. Augustine.

\section{Further Understanding on Hsun Tzu's Evil}

To further understand Hsun Tzu's evil, two questions should be raised. First, what is human nature; second, how do we understand categories of evil? In conformity with perspectives of Hsun Tzu, human nature includes three levels of meaning. "First, human nature is inborn not nurtured or artificial. Second, in the respect of its feature, human nature is simple and plain without adornment or polish, which is subject to its innate condition. Third, considering the context of human nature, it contains all kinds of physical needs and desires for living” (Xia, 1987). Knowing what human nature means, the following one is the explanation of evil. Evil in terms of Hsun Tzu can be 
classified into two aspects-physical evil and moral evil. Moreover, Hsun Tzu emphasizes on moral evil. "Desire and morality are incompatible. Any one who follows his nature and indulges his emotions will inevitably violate the forms and rules of society and will end up as a criminal" (Plutschow, 2002). Morality is an important key to control human desires. Morality is like an alarm that prevents them from falling. As long as human desires are excessive; the morality will stop them. Besides, rules which are set up by wise kings or monarchs are also important. Actually, evil advanced by Hsun Tzu is totally different from good human nature in Confucianism. Let's compare the ideas of evil by Hsun Tzu with the ideas of good by Mencius. According to Herbert Plutschow's Hsun Tzu and the Ancient Chinese Philosophical Debate on Human Nature.

Because of an idealist that he was, Mention believed in the innate goodness of man. He believed that man's ability to learn how to be a good and responsible citizen stems from and thrives upon his innate goodness. If man were not innately good, Mention argued, how could he possibly learn to be a good citizen? However, Hsun Tzu maintained that man is bad and that the state needs to control and guides him to becoming a good citizen. Mencius nevertheless maintained that the individual must cultivate and the state must nurture, guide, and help maintain his goodness (Plutschow, 2002).

In fact, good human nature Mencius' thoughts may be regarded as transcendentalism. However, "Hsun Tzu, to a certain extent, doubts predetermined moral values which belong to Confucius and Mencius” (Xia, 1987). Hsun Tzu considers that human nature is inherent rather than nutured. In his masterpiece Hsun Tzu, he describes how evil in human nature forms: "selfishness is inborn in human nature; once it expands, the dispute follows and the modesty falls; jealousy is inherent in human nature; once it extends, the conspiracy forms and the sincere advice loses” (Hsun Tzu, 2004). Therefore, evil in human nature is the result of undisciplined physical needs. And if human nature is not undisciplined and human desires are not inhibited, Hsun Tzu considers that the feudal hierarchical system and moral norms will be violated and destroyed, which may lead to disorder and riot.

\section{Their Differences}

\section{Comparing Their Different Backgrounds}

St. Augustine lives in a crucial period in the history of Christianity. In the later period of Roman Empire, slave owners implement barbarous and ruthless dictatorship which brings people extreme bitterness and misfortune. "It exposed the unprecedented weakness and the impracticality of realistic blissful theories which were created by ancient Greek philosophers who were optimistic in treating evil in real life" (Yang, 2000). Under this situation, the whole society calls ideologists to give another convincing answer about the resource of evil human nature. St. Augustine, who stands on the side of Christian theology, answers this urgent call in that era. In the attempt to put down lots of heresies, Saint Augustine makes great efforts to set up his theories. In the book Great Traditions in Ethics written by Denise White Peterfreund, it says that:

In the support and defense of Christian doctrine, Augustine is obliged to resolve some of the most troublesome metaphysical problems of ethics. Among these, the most crucial challenge to the effectiveness of his ethical theory and a natural point of entry into his whole moral philosophy is the so-called problem of evil namely, how to reconcile the existence of evil in the world with the omnipotence and benevolence of God (Peterfreund, 2003).

Evil human nature proposed by Hsun Tzu came out as early as it proposed by St. Augustine. In the course of Chinese Warring States Period (475-211 BC), ancient Chinese slavery collapsed and crumbled with the development of society. Chinese feudalism was gradually taking on the shape and newly emerging landlord class was appearing on the historical stage. On the basis of these, Warring States produced a special phenomenon in field of ideology which was the contention and flourishing of numerous schools of thought and the ideas of Hsun Tzu also belonged to them. Hsun Tzu was born in 316 BC, and at age of fifteen he had traveled around to study and spread his ideas. He stands for the newly emerging landlord class. Thereby, his ideas are more or less to defend interest of landlord class.

\section{Comparing Their Ways for Salvations}

\section{The Use of Free Will to Accept and Follow Grace of God}

In the view of St. Augustine, human beings converting evil into goodness have a bearing on two points the free will of human beings and the grace of God. Free will which is the source of evil signifies that in front of evil and goodness human beings have rights to choose. So, one can alter good to live a moral life or continue to be evil. Goodness is the grace of God. "Ask, and it will be given you; search, and you will find; knock, and the door will be opened for you" (Holy Bible, 2004). Being good is not mandatory or peremptory; on the contrary, it depends on the awareness of individuals. Good human nature never exists in human innate. Goodness is the privation of evil. Because human beings cannot seek for goodness from inside, they turn to outside to pursue it. "It is both the gift of God and free choice that some accept this word which not all accept" (Brown, 2005). Where do they seek for goodness? And what is outside? God, the answer to these two questions is God. From the grace of God human beings can get their goodness, for God himself being all-good and having powers to give goodness to human beings. Human beings use free will to accept or reject goodness. If they use free will to reject the gift of God, evil will follow. To name but one example, in the story of Holy Bible Adam and Eve do not resist the temptation from the snake. It can be understood that Adam and Eve choose evil to eat forbidden fruit on wise tree. In other words, although Adam and Eve have rights to be good, they choose evil instead following the grace of God. Accordingly, human beings have to turn to human outside-God-to pursue goodness. In his masterpiece Confessions, St. Augustine says, "And now thou didst 'stretch forth thy hand from above' and didst draw up my soul out of that profound darkness" (Augustine, 2003). It means that evil human nature can only be saved by the blessing of God. The only way leading to freedom and be good is to accept and follow the grace of God. Nothing stands in the way for human beings to pursue goodness as long as they accepting the blessing of God. Goodness always exists, for God owns and offers it. Consequently, goodness is independent on evil human nature. In the book Great Traditions in Ethics written by Denise White Peterfreund, it says, "Knowledge of God is indispensable to our blessedness. But, Augustine holds that it is false pride for people to believe that they can know God through their own efforts. Only when God by His grace illuminates the mind can it grasp the truth. Similarly, salvation can be achieved only through God's grace.” (Noel, 2004) That is to say, goodness does not belong to human beings or exists in human nature, because its master is God. Apart from this, it also shows that human beings 
do not attain goodness, though they are on their own initiative to seek for it. The only way to get goodness is from God. This view completely ignores the initiative of human beings. But we cannot deny that God is the master of goodness.

\section{Emphasis on Proprieties and Rules Formed by Saints and Monarchs}

However, in accordance with Hsun Tzu, he considers that human nature is evil inborn. If human beings want to attain goodness, they have to learn from saints and obey social proprieties and laws. It implies that human beings have to convert evil into goodness for evil human nature is inherent. To a certain extent, it is a bit of obligation. According to his masterpiece Hsun Tzu, "proprieties, which were produced by saints, could be attained by assiduous study of human beings" (Hsun Tzu, 2004). A question can be raised: where do proprieties come from? To answer this question, Hsun Tzu states his own opinions. Saints to think and do that generate a great deal of experience and knowledge which proprieties are derived from. Therefore, proprieties originate from acquired assiduity of saints not their human nature. It does not mean that saints have goodness innate. On the basis of proprieties, saints and wise monarchs create laws to govern feudal countries and their citizens. Proprieties and laws are extremely close with each other. Proprieties focus on values of morality and outlooks on life, while laws emphasize the punishment. "Laws are absolutely necessary to social administration” (Chen \& Xiao, 2006), of course, "using laws is just a method to reform human nature not the final purpose" (Wang, 2008). In order to vividly explain approaches of Hsun Tzu to convert evil into goodness, an obvious example can be taken. Last year has witnessed the beginning of a worldwide financial crisis which stemmed from United States. The worldwide financial crisis is still lasting and spreading. This financial crisis firstly occurs in real estate market and stock market. In recent years, real estate investment arises and has extortionate profits. The extortionate profits attract increasing Americans to invest real estate with credit cards, which incurs many people to invest real estate with unreal finance. Indulging in the extortionate profits, people are never bored with this hazardous financial game. The following result is the breakout of financial crisis. Leaving the economic reason aside, let us consider this crisis from the angle of philosophy. This financial crisis stems from evil human nature. Human beings do not inhibit their desires for finance. If people who madly cling to real estate investment control their desire to attain profits, this worldwide financial crisis may be avoided. Besides, if laws of real estate investment are strengthened, the loss from this crisis may be reduced to the minimum. It shows that proprieties and laws are necessary and significant to mould people's values and restrict their actions.

\section{Comparative Analysis of Their Positions of Human Beings}

In accordance with the doctrines of Christianity, all human beings are equal in the eyes of God. Accordingly, positions of people in Augustinian theology are equal. According to Great Traditions in Ethics written by Denise White Peterfreund, "Adam, the first man, chose evil, thus falling from God's favor, and his original sin are inherited by all human beings. Each person is predestined by God either to salvation or to damnation” (Peterfreund, 2003). We can see that though positions of the Pope and clergymen are distinguished from positions of ordinary people, in fact they are the same in essence and in the charge of the same master God. Meanwhile, the disparities are further eliminated and removed by religious reform which is sponsored by Luther and Calvin. Henceforth, clergymen have the same position facing grace of God as ordinary people and only difference lies in their different tasks.

On the other hand, evil human nature in Hsun Tzu's thoughts emphasizes that people are not in equal positions, which is an apparent opposition to the view of St. Augustine. Not only does Hsun Tzu consider that human nature are evil, but also draws clear lines of demarcation between saints and ordinary people, between monarchs and their subjects. Moreover, he attaches great importance to feudal hierarchy. On the part of human nature saints have no difference from ordinary persons, however, "what they differentiate and surpass ordinary persons is that they have goodness which forms proprieties and laws by acquired learning” (Hsun Tzu, 2004). Monarchs are located at the top of the feudal system and own supreme powers. They can make policies and use their powers without restriction and limitation; meanwhile, "monarchs are permitted to neglect their evil human nature and highly praised to maintain their prestige and dignity" (Wang, 2008). Besides, unequal positions also include the relationships between husbands and wives, between fathers and sons, between younger brothers and elder ones. Wives conform to their husbands, sons follow fathers, and younger brothers obey elder ones.

\section{St. Augustine More Welcome than Hsun Tzu}

St. Augustine enjoys the great honor in the whole philosophical history in the West, so his perspectives, such as evil human nature, free will, grace of God, freedom, views of time and space, predestination and so on, greatly influence western philosophy. He is the first Christian philosopher to formulate the doctrines of Christianity in a comprehensive and enduring world view. His thoughts dominate Christian beliefs almost exclusively for more than nine centuries. In elaborating the Christian revelation, he dedicates himself into the task of showing the way to the spiritual safety and happiness of salvation. Consequently, he carries on an unrelenting campaign to root out the heretical beliefs that mislead human beings in seeking for the true religion. In addition, he undertakes the construction of a reasonable defense against charges of conflicts, paradoxes, contradictions, and absurdities in Christian doctrines. His accomplishment is facilitated by effective combination of Greek philosophy and Christian belief. "St. Augustine is called by church 'great guide', 'the saint of God', and 'doctor of church'; meanwhile, he is an important spiritual guide for forefathers of religious reformers Luther and Calvin" (Jiang, 2008). Apart from this, he integrates theories from Plato with Christian theology.

In comparison with St. Augustine, ideas of Hsun Tzu go up and come down in the whole course of Chinese history. Most of the time, it suffers from neglect and rejection. Because of his holding on evil human nature, he is different from other major thinkers of Confucianism believing good human nature. Moreover, "he denies the innate moral values, the inborn saints, and the supreme power of monarchs being bestowed from hea- ven" (Xia, 1987). The thought of Hsun Tzu was the official creed during Han and Tang Dynasties. But all his ideas are not beneficial to monarchs. Hence, they are rejected by most monarchs, especially in Song and Ming Dynasties. In fact, evil human nature posed by Hsun Tzu is considered a positive and progressive view, to a certain extent. It admits human initiative and advances the progress of history to some degree. Of course, Hsun Tzu has other positive points, such as the relationship between monarchs and citizens like the boat and the river that 
river can load the boat and even flood it, man triumphing over nature, and so on. Recently, researches on evil human nature posed by Hsun Tzu are increasing because of its theoretical and realistic significance in this material overflowing era.

\section{St. Augustine's Thought Belonging to Religion While Hsun Tzu's Morality}

The perspective of evil human nature by St. Augustine belongs to religious category, which "is the part of Christianity original sin" (Chen, 2002); but the idea of evil human nature by Hsun Tzu can be sorted out to the category of moral realm. Why? How do we understand them? St. Augustine's view, deriving from Socrates and Plato, metaphysical to some extent, belongs to the transcendentalism. God has supreme goodness; meanwhile, human beings cannot match or attain this supreme one. Goodness human beings seeking for are subordinate to God's. In other words, God not only creates all kinds of creature from nihilistic world, but also commands goodness.

St. Augustine says that God is the source of goodness and creatures are arranged by their degrees of goodness. "God alone is intrinsically good. The individual virtues are simply different aspects of the love of God" (Noel, 2004). When human beings are created by God, they also are endowed with abilities to think, recognize, and to choose evil or good. Accordingly, human nature does not have goodness, let alone the supreme goodness.

On the other hand, evil human nature in Hsun Tzu's thoughts belongs to the category of morality, "his view just belongs to moral realm” (Chen, 2002). His idea is initially based on the humanism and pays an attention to morality. Because Hsun Tzu may be an atheist on the issue of evil and his concept of evil originates from social reality, he emphasizes on morality to defend feudal system, such as, moral laws, moral proprieties and moral principles. In the book Philosophy: the Power of Ideas written by Brook Noel Moore, "The hierarchical order of society is set up through following unchanging moral principles. If moral practices, laws, and the rules of propriety are followed, order, peace, and prosperity will inevitably be the result. If they were not followed, disorder and disaster will result" (Noel, 2004). Because of his view of evil belonging to moral realm, nurture on morality is extremely necessary.

\section{Their Similarities}

\section{Evil both Physical and Moral}

Both St. Augustine and Hsun Tzu confirm that human nature is evil without goodness innate. Besides, they both reach agreement on evil including two levels. "There are two levels of meaning on evil physical evil and moral evil” (Zhou, 2007). The former one depends on the physical existence of human beings and human beings need food, clothing, shelter and means of travel. Moreover, physical evil also includes physical weakness, such as blindness and deafness. St. Augustine and Hsun Tzu do not deny physical needs for human living. When desires for living are not inhibited, evil comes. Then, the later one depends on individual moral consciousness. Apart from this, they both emphasize on the usage of nurture and cultivation. They believe that education is helpful to human beings convert evil into goodness.

\section{In a Tint of Their Times}

Both of them have their own limitations on evil human nature. These limitations mainly originate from realities of their own eras. St. Augustine lives in the later period of Roman Empire. "He was the last of the great late ancient philosophers. Between the sixth century and the eleventh, Europe went through the Dark Ages” (Noel, 2004). Under that cruel and ruthless situation, a lot of heresies were rising. Paradoxes and conflicts in these different religious schools were continually aggravated. In order to maintain the dominant position of Christianity and unravel the puzzle on evil, St. Augustine puts forward his theories. One typical feature of his perspectives is to digest thoughts of ancient philosophers Plato, especially Plato's New Principles on freedom. The other typical feature is that his thoughts are more or less imprinted with Christian doctrines and stand for the class which he belongs to. When St. Augustine puts forward his evil human nature, he has become a clergyman in northern Africa, which shows that he actually acts for the interest of the Pope and clergymen. Besides, in St. Augustine's thoughts, it implies that "it totally denies human initiative to seek for goodness and truth” (Yang, 2000). Although human beings have free will to choose evil or goodness, it does not mean that they seize the initiative during seeking for the goodness. Because human beings do not know what goodness is when they are beset with inborn evil, they only follow the way God offers to attain goodness.

On the other hand, Hsun Tzu lived in the course of Chinese Warring States Period. During that era, slavery was gradually removed with the disappearance of slave economy. At the same time, feudal economy was forming. Hsun Tzu is one of these newly emerging classes landlord class. Because of the representative of newly emerging landlord class, Hsun Tzu undoubtedly acts for the interest of landlord class. His ideas about proprieties and laws are on the standpoint of landlord class and in the name of saints and wise monarchs to set up feudal countries and execute the centralization. Besides, the purpose of his views is to strengthen feudal system and enhance powers of landlord class. To be a thinker standing for the newly emerging landlord class, especially in order to landlord class totally grasp the initiative, Hsun Tzu pays his attentions to the establishment and enhancement of feudal system that requires subjects to form firm values of feudal morality and laws and rigidly obey these. Apart from these, both of their perspectives, to a certain extent, refer to the views about politics. Of course, most of the points about these also depend on realities of their own eras, which have obvious limitations. Accordingly, no matter evil human nature and its solution from Augustine or from Hsun Tzu, they are both in the tint of their own times.

\section{Conclusion}

The thesis initially explains what evil is in St. Augustine's and Hsun Tzu's thoughts. It presents a general impression of evil. And through their explanations, it can be seen that these two perspectives have apparent distinction. From differences and similarities of evil human nature in these two, we get a whole picture about them. The comparison reveals that differences between the perspective of St. Augustine and that of Hsun Tzu account for the most important part. Differences of these two points are further divided into five sub-types, including their different backgrounds, ways to convert evil into good, positions of human beings, historical status, and categories. In fact, ways to convert evil into good are the major part in distinction. To illuminate their different ways, my thesis takes two relatively typical examples to explain and express them, which make it easy to comprehend the major part of distinction between these two thinkers on evil human nature. Apart from their dis- 
tinction, the thesis adds their similarities to complement and perfect comparison and analysis of evil human nature in St. Augustine's and Hsun Tzu's thoughts. After the whole comparative analysis, it naturally draws two obvious conclusions. First, evil human nature proposed by Hsun Tzu is simple in connotation and relatively objective compared with the evil proposed by St. Augustine. In the views of St. Augustine's evil, there is an apparent contradiction in his theories. Evil is the privation of goodness, which is original from the free will of human beings. However, in his later years, St. Augustine proposes his ideas of predestination. God foresees everything, so he also has the foreknowledge that human beings may choose evil with free will. That is to say, God has the great power to prevent evil, so evil does not come from free will. In comparison with these, Hsun Tzu's view is simpler and more objective. His idea of evil results from desires for living. He views evil from the angle of social reality. Therefore, his view is more objective. Second, St. Augustine deems that human being are equal in front of evil, which has positive significance compared with the view proposed by Hsun Tzu who insists on the disparities between saint and ordinary people, between monarchs and their subjects. In the eyes of God, human beings are equal even with evil. Because of Hsun Tzu's idea based on social reality, it is definitely affected by reality. In order to defend the feudal hierarchy, he distinguishes saints and wise kings from ordinary people and subjects. They are subordinate to saints and kings. In this respective, the view of evil by St. Augustine is more positive than it by Hsun Tzu. According to these conclusions, we can see that these two ideas of evil have their own merits on different levels. Consequently, we cannot consider evil in these two without close observation.

\section{References}

Augustine, St. (1953). To simplician on various questions, in augustine: earlier writings. London: The Westminster Press.
Augustine, St. (2003). Confessions. Beijing: HuaWen Press

Battle, J. (1996). How can god be just and ordain evil. Western Reformed Seminary Journal, 3, 1.

Brown, M. (2005). Augustine on freedom and God. The Saint Anselm Journal, 2, 50-65.

Campbell, R. (2001). The covert metaphysics of the clash between "Analytic" and "Continental" philosophy. British Journal for the History of philosophy, 9, 341-359. doi:10.1080/09608780110045335

Chen, J.-Y. (2002). Comparison Western evil human nature in West and East and their policital influences. Qinghai Social Sciences, 6, 113-115.

Chen, Y.-G., \& Xiao, J.-P. (2006). The definition of Hsun Tzu's evil human nature. Journal of Hengyang Normal University, 27, 22-27.

Duong, K. (2009). Philosphy of evil from a Kant and St. Augustine perspective. URL (last checked 2009)

http://www.associatedcontent.com/article/1479734/philosphy_of_evi l_from_a_kant_and_st.html?cat=47

Hexter. (2009). Augustinian theodicy. URL (last checked 2009) http://everything2.com/title/Augustinian\%2520Theodicy

Holy Bible, (2000). National TSPM \& CCC.

Hsun Tzu. (2004). Hsun Tzu. Inner Mongolia Autonomous Region: Distant Press House.

Jiang, P. (2008). The basic paradigm of augustine and the Christian theology. Journal of Guangzhou Institute of Socialism, 1, 74-77.

Koukl, G. (2005). Augustine on evil. URL (last checked 2009) http://www.believersweb.org/view.cfm?ID=1077

Noel, M. B. (2004). Philosophy: The power of ideas. New York: McGraw-Hill Companies Press.

Peterfreund, D. W. (2003). Great traditions in ethics. Beijing: Peking University Press.

Plantinga, A. (2000). Warranted Christian belief. Oxford: Oxford University Press. doi:10.1093/0195131932.001.0001

Wang, Y.-M. (2008). Comparison of Chinese and Western evil human nature and its significance. Journal of Tianjin Normal University (Social Science Edition), 4, 1-5.

Xia, Z.-T. (1987). The philosophy of Hsun Tzu. Shanghai: Shanghai People Press House.

Yang, M.-M. (2000). Augustine's theory of sin. Journal of Anqing Teachers College (Social Science Edition), 19, 83-88.

Zhou, L.-X. (2007). Analysis of Augustine's treatment of the problem of evil. Journal of Yunnan Univeristy (Social Science Edition), 6, 58-66. 